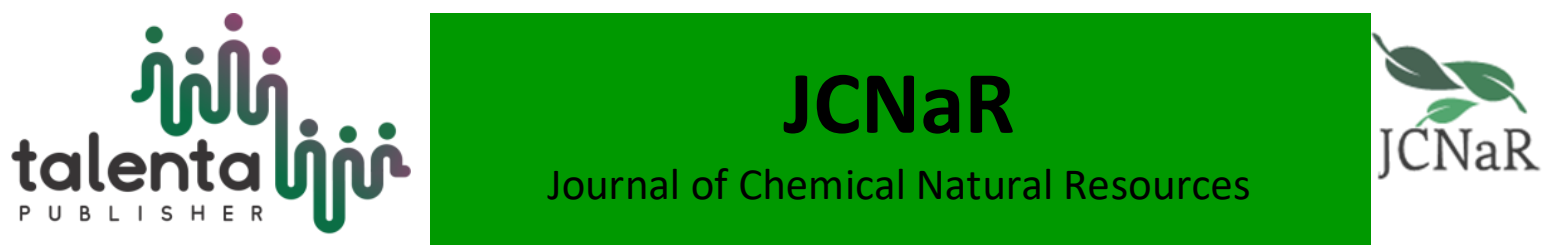

\title{
Antimicrobial Activity of Dadap Serep (Erythrina subumbrans (Hassk.) Merr.) Leaves Extract
}

\author{
Diah Tri Utami' ${ }^{1}$ Fitrianingsih'2, Indri Maharini ${ }^{3}$ \\ ${ }^{1,2,3}$ Department of Pharmacy, Faculty of Science and Technology, Universitas Jambi
}

\begin{abstract}
The leaves of Erythrina has been used in Indonesia as a remedy for rheumatism, stomach-ache, asthma, dysentery, contact dermatitis, eczema and skin infections. However, there have been limited phytochemical or biological studies on the leaves of E. subumbrans and there are not studies that align with its traditional medicinal uses. The aim of this study was to assess the antimicrobial activity of the leaves of E. subumbrans to support its topical use in the treatment of skin infections. Disc diffusion agar assays were used to determine the antimicrobial activities of ethanol extracts of the leaves of E. subumbrans. The ethanol extracts showed the most significant activity with MIC values of 0.5 $\mu \mathrm{g} / \mathrm{mL}$.against a sensitive strain of Staphylococcus epidermidis. Extract concentration of $0.5 \mathrm{mg} / \mathrm{ml}, 1 \mathrm{mg} / \mathrm{ml}, 5 \mathrm{mg} / \mathrm{ml}$ and $10 \mathrm{mg} / \mathrm{ml}$ showed inhibition zone continuously as high as $1.83 \mathrm{~mm} ; 3.42 \mathrm{~mm} ; 5.17 \mathrm{~mm}$ and $8.00 \mathrm{~mm}$. The ethanol extracts of the leaves of E. subumbrans also showed significant activity against Candida albicans with MIC values of $0.5 \mu \mathrm{g} / \mathrm{mL}$. Extract concentration of $0.5 \mathrm{mg} / \mathrm{ml}, 1 \mathrm{mg} / \mathrm{ml}, 5 \mathrm{mg} / \mathrm{ml}$ and $10 \mathrm{mg} / \mathrm{ml} \mathrm{showed}$ inhibition zone continuously as high as $4.00 \mathrm{~mm} ; 4.17 \mathrm{~mm} ; 5.25 \mathrm{~mm}$ and $6.50 \mathrm{~mm}$. Bioactive substance test showed that alkaloid, flavonoid, saponin, and triterpenoid were found in E. subumbrans extract indicates potential activity as antimicrobial agent. These results provide support for the customary (traditional and contemporary) use of E.subumbrans leaves for the treatment of nosocomial infections.
\end{abstract}

Keyword: Antimicrobial, Candida albicans, Erythrina subumbrans, Staphylococcus epidermidis.

Received November 1, 2018| Revised December 15, 2018 | Accepted January 20, 2019

\section{Introduction}

Candida albicans (C. albicans) and Staphylococcus epidermidis (S. epidermidis) are the most commonly known around the world as the nosocomial infecting microbes, which also means the cause of escalation in morbidity rate, mortality and medical costs. C. Albicans is one of fungi species from Candida genus and normal flora in the digestive tract, mucous membrane, respiratory tract, vagina, urethra, skin and beneath the nails. C. Albicans can possibly be a pathogen which causes infections, such as septicaemia, endocarditis or meningitis (Simatupang, 2008). While S. Epidermidis is one of the species from the genus of Staphylococcus bacteria, which is normally found in clinical cases. These bacteria are called gram-positive bacteria and

\footnotetext{
*Corresponding author at:Department of Pharmacy, Faculty of Science and Technology, Universitas Jambi, Jambi and Indonesia

E-mail address: diahtriutami@unja.ac.id
} 
included in staphylococcus with negative coagulation. The majority parts of these bacteria are normal flora on human skin and mucous membrane (Jawetz, 2010).

The number of infectious diseases on human caused by fungus and bacteria is still relatively high. In the past, these microbes almost never resulted any significant infections. However as the use of catheter implant and prosthetic tools increases, C. albicans and S. Epidermidis have now become the main cause of nosocomial infections (Soedarto, 2016).

The treatments for microbial infections have become more complicated because of the increasing resistance upon antimicrobial agents and their capability to form the biofilm (Nuryastuti, et. al. 2009). For approximately $75 \%$ of S. Epidermidis isolates have experienced the resistance over nafcillin, oxacillin, methicillin and penicillin (Jawetz, 2010). On the other hand, $C$. Albicans experience resistance over azole, fluconazole, echinocandin and amphotericin B (Kellya et al., 1997; Morschhäuser, 2016). This high rate of resistance will tribulate the treatments on infections and will cause higher medical costs for patients (Aloush et al, 2006). Therefore, it is essential to conduct research activities on natural antimicrobials development of E.subumbrans leaves.

\section{Materials and Methods}

The main ingredient in this research is the dried powder of E.subumbrans leaves, collected from Kuamang, Jambi. The microbes samples used in this research are the pure cultures of Candida albicans fungi and S. Epidermidis bacteria obtained from Biotechnology Laboratory and Science and Technology Engineering Faculty at the University of Jambi. The medium utilized in antifungal activity is PDA (Potato Dextrose Agar), while for antibacterial activity is NA (Nutrient Agar). Other than those, some kinds of solvents are used to concoct extracts and to screen the phytochemical from the obtained extracts.

\subsection{The Extraction of $E$. Subumbrans}

Satu kg of dried E.subumbrans leaves grinded to powder. The method of extraction with $70 \%$ ethanol is conducted by maceration. The macerate is then concentrated by rotary evaporator on $50^{\circ} \mathrm{C}$ temperature and the speed of $50 \mathrm{rpm}$. Afterwards, it is dried in oven on $40^{\circ} \mathrm{C}$ temperature until the fixed quality is obtained.

\subsection{Phytochemical Screening}

Phytochemical screening is conducted on the extracts via qualitative analysis of tannins, phenols, alkaloids, flavonoids, saponins, and triterpenoids components.

\subsection{Antimicrobial Activities Test}

The antimicrobial activity on $C$. Albicans fungi and S. Epidermidis bacteria are conducted by using the method of disc diffusion agar, with some variety of extract concentrates in the amount 
of $0.5 \mathrm{mg} / \mathrm{ml}, 1 \mathrm{mg} / \mathrm{ml}, 5 \mathrm{mg} / \mathrm{ml}$ and $10 \mathrm{mg} / \mathrm{ml}$. The concentrate used is DMSO for $10 \%$. Negative controls normally use DMSO 10\%, while positive controls use clindamycin for $S$. Epidermidis bacteria and histatin for C. Albicans fungi. The incubation is executed within 24 hours, while inhibition zone around the paper disc is measured in four repetitions using the slide bar.

\section{Results and Discussion}

\subsection{Phytochemical Screening}

This is the qualitative test on bioactive components in order to recognize the compounds in E.subumbrans leaves extracts. This phytochemical test refers to phytochemical screening method. The results of bioactive test are presented in Table 1 .

Table 1. The results of phytochemical screening on E.subumbrans leaves extracts

\begin{tabular}{cc}
\hline Test & E.subumbrans leaves extracts \\
\hline Tanin & + \\
Fenol & + \\
Alkaloid & + \\
Flavonoid & + \\
Saponin & + \\
Triterpenoid & + \\
\hline
\end{tabular}

Refering to the results above, E.subumbrans leaves extracts contain tannin, phenol, alkaloid, flavonoid, saponin and triterpenoid.

\subsection{Antimicrobial Activities Test}

According to the measurement results, in negative control with DMSO 10\% on C.albicans fungi and S.epidermidis bacteria, the zone of inhibition has a diameter of $0 \mathrm{~mm}$, which means that the solvents do not produce any antimicrobial activity, thus, are not capable of preventing the growth of $C$. albicans and S. epidermidis. The results of activity are presented in table 2.

Tabel 2. The results of antimicrobial activity on C.albicans fungi and S.epidermidis bacteria

\begin{tabular}{lcc}
\hline \multicolumn{1}{c}{$\begin{array}{c}\text { Solvent Concentrate } \\
(\mathrm{mg} / \mathrm{ml})\end{array}$} & \multicolumn{2}{c}{ Zone of Inhibition (mm) } \\
\cline { 2 - 3 } & C. albicans & S. epidermidis \\
\hline EDDS 0,5 & 1.83 & 4.00 \\
EDDS 1 & 3.42 & 4.17 \\
EDDS 5 & 5.17 & 5.25 \\
EDDS 10 & 8.00 & 6.25 \\
Clindamicyn & 0 & 22.50 \\
Histatin & 14.38 & 0 \\
DMSO 10\% & 0 & 0 \\
\hline
\end{tabular}

Annotation

Data are obtained after the decrease of paper disc diameter for $6 \mathrm{~mm}$

Data are in approximate results after three repetitions 
Clindamycin: positive controls

DMSO 10\% : negative controls

It is seen from the results that when combined with some concentrates, E.subumbrans leaves extracts are able to prevent the growth of $C$. albicans fungi and S. epidermidis bacteria. According to the previous study, the stem extracts from Erythrinapoeppigiana show antimicrobial activity towards C. Albicans and methicillin-resistant Staphylococcus aureus (MRSA) (Sato, et al., 2003), while the bark extracts from Erythrina caffra show antimicrobial activity towards some gram-positive and gram-negative, also to some species of fungi (Olajuyigbe and Afolayan, 2012).

It is assumed that antimicrobial compounds in E.subumbrans leaves extracts consist of various compounds with diverse polarities. This happens because the samples are crude extracts. Based on the results of phytochemical isolation on E. Poeppigiana, the compounds acting as antimicrobials come from isoflavonoids class (erypoegin A, dimethylmedicarpin and sandwicensin), methyldeoxybenzoin (angolensin) and cinnamylphenol (erypostyrene) (Sato, et al., 2003).

According to Morschhäuser (2016), fungistatic compounds such as phenolic are capable of performing protein denaturation, meaning the process of damaging protein tertiary structure so the protein loses its genuine characteristics. This denaturation process on C. albicans protein wall will cause fragility on the cell wall, causing an easy perforation by other fungitastic active substances. If the denaturated protein is in the form enzyme protein, then enzyme is not able to perform its function, causing disturbance in metabolism and the process of nutrient absorption. Based on the classification, the zone of inhibition shaped by $5,1,5$ and $10 \mathrm{mg} / \mathrm{ml}$ concentrates has the approximate size of $1.83-8 \mathrm{~mm}$, showing the potential of E. Subumbrans leaves extracts to prevent the growth of fungi. Antibiotic or antibacterial in $20 \mathrm{~cm}$ intensity will perform activities intensely, in $10-20 \mathrm{~mm}$ powerfully, $5-10 \mathrm{~mm}$ fairly, while $5 \mathrm{~mm}$ or less will perform weakly.

\section{Conclusion}

Referring to results and discussion, it can be concluded that the antimicrobial compounds from E.subumbrans leaves extracts contain alkaloids, flavonoids, saphonins and triterpenoids. The Minimum Inhibitory Concentration (MIC) towards C. Albicans fungi on $0.5 \mathrm{mg} / \mathrm{ml}$ E.subumbrans leaves has the zone of inhibition as high as $4.00 \mathrm{~mm}$, while the optimum capacity in concentrate is $10 \mathrm{mg} / \mathrm{ml}$ with zone of inhibition of $6.50 \mathrm{~mm}$. The Minimum Inhibitory Concentration (MIC) towards S. Epidermidis bacteria on $0.5 \mathrm{mg} / \mathrm{ml}$ E.subumbrans leaves has the zone of inhibition as high as $1.83 \mathrm{~mm}$, while the optimum capacity in concentrate is 10 $\mathrm{mg} / \mathrm{ml}$ with zone of inhibition of $8.00 \mathrm{~mm}$. 


\section{Acknowledgement}

To the Faculty of Science and Technology, Universitas Jambi, for providing facilities to this research.

\section{References}

Aloush, V., Navon-Venezia S, Seigman-Igra Y., 2006, Multidrug-Resistant Pseudomonas aeruginosa: Risk Factors and Clinical Impact. Antimicrobial Agents and Chemotherapy, 50(1), pp.43-48

Jawetz, E., Melnick, J., 2010, Review of Medical Microbiology 15th edition, California, Lange Medical Publication.

Kellya, S.L., D.C. Lamba., D.E. Kellya., N.J. Manningb., J. Loefflerc., H. Hebartc., U. Schumacherd., and H. Einselec., 1997, Resistance to Fluconazole and Cross-resistance to Amphotericin B in Candida albicans from AIDS Patients Caused by Defective Sterol $\Delta 5,6$ Desaturation, FEBS Letters, 400 (1), pp.80-82.

Morschhäuser, J., 2016, The Development of Fluconazole Resistance in Candida albicans - an Example of Microevolution of a Fungal Pathogen: Review Biology of Human Fungal Pathogen, Journal of Microbiology, 54 (3), pp. 192-201.

Nuryastuti.T., Henny C. Van Der Mei, Henk J. Busscher, Susi Iravati, Abu T. Aman and Bastiaan P. Krom, 2009, Effect Of Cinnamon Oil On Icaa Expression And Biofilm Formation By Staphylococcus epidermidis, Applied And Environmental Microbiology, Vol. 75, No. 21, pp. 6850-6855

Olajuyigbe, O. O., and A. J. Afolayan., 2012, In vitro pharmacological activity of the crude acetone extract of Erythrina caffra Thunb: Antibacterial and Antifungal Assessment, Journal of Medicinal Plants Research, 6 (9), pp. 1713-1720.

Sato, M., H. Tanaka, R. Yamaguchi, T. Oh-Uchi, and H. Etoh, 2003, Erythrina poeppigianaDerived Phytochemical Exhibiting Antimicrobial Activity Against Candida albicans and Methicillin-resistant Staphylococcus aureus, Letters in Applied Microbiology, 37, pp. 8185.

Simatupang M.M., 2008, Candida Albicans, Departemen Mikrobiologi fakultas Kedokteran, Universitas Sumatera Utara.

Soedarto, 2016, Infeksi Nosokomial Di RumahSakit, Edisi Pertama, Cetakan Pertama. CV. Sagung Seto, Jakarta. 